\title{
ТИПОМОРФНI
}

\section{ОСОБЛИВОСТІ ЗОЛОТА}

\section{3 КОРИ ВИВІТРЮВАННЯ СУРСЬКОЇ ЗЕЛЕНОКАМ'ЯНОÏ СТРУКТУРИ}

\author{
Мирон \\ КОВАЛЬЧУК \\ доктор геологічних \\ наук, професор, \\ завідувач відділу \\ Інституту геологічних \\ наук НАН України, \\ член Спілки геологів \\ України \\ Віталій \\ СУКАЧ \\ доктор геологічних \\ наук, завідувач відділу \\ Інституту геохімії, \\ мінералогії та \\ рудоутворення \\ ім. М.П. Семененка \\ НАН України, член \\ Спілки геологів \\ України
}

\begin{abstract}
На підставі узагальнення фактичного матеріалу виробничих звітів, публікацій у наукових виданнях та власних досліджень наведено відомості щодо типоморфних особливостей самородного золота з кори вивітрювання різного мінерального складу золотоносних порід фундаменту в межах родовищ і рудопроявів Сурської зеленокам'яної структури. Досліджено зміну типоморфних особливостей золота у вертикальному розрізі кори вивітрювання.
\end{abstract}

Ключові слова: Середньопридніпровська граніт-зеленокам'яна область; Сурська зеленокам'яна структура; кора вивітрювання; золото; типомофні особливості.

\section{ВСТУП}

Значна кількість великих родовищ золота в межах кристалічного фундаменту давніх платформ світу, зокрема й на Українському щиті, приурочена до ранньодокембрійських граніт-зеленокам'яних поясів. У більшості структур Середньопридніпровської граніт-зеленокам'яної області теж наявна золоторудна мінералізація. Золоторудні об'єкти Середньопридніпровської граніт-зеленокам'яної області належать до родовищ і проявів гідротермально-метасоматичних руд, приурочених до архейських зеленокам'яних структур, які зіставляються з добре відомими крупними архейськими родовищами провінцій давніх кристалічних щитів Канади, Австралії та інших, у яких родовища золота розташовані поміж змінених вулканогенних порід основного складу та залізистих кварцитів, що тісно асоціюють із субвулканічними гіпабісальними диференціатами основної магми (Гаєва та ін., 2006; Сукач та ін., 2006). Однією з найбільш вивчених і багатих на золото є Сурська зеленокам'яна структура, що виповнена мезоархейськими стратифікованими петротипами конкської серії, у складі якої виокремлюють (знизу вгору): сурську світу, аполонівську товщу, алферівську світу та пашенівську товщу, а також синхронні їм інтрузивні та субвулканічні утворення (верхівцевський базит-ультрабазитовий комплекс, сергіївська асоціація метагаброїдів) (Гаєва та ін., 2006; Сукач та ін., 1999, 2006). Із завершальним етапом формування структури пов'язано укорінення сурського плагіогранітоїдного комплексу (Гаєва та ін., 2006). В їі межах виявлено два родовища золота (Сергіївське і Балка Золота), перспективні рудопрояви (Аполонівський, Східно-Аполонівський, Тетянин, Розрахунковий, Дорожній, Новий, Новий-1, ПівденноПетрівський, Північний, Карнаухівський, Правдинський, Павлівський, Північносурський), десятки пунктів мінералізації золота в кристалічних породах, їхній корі вивітрювання, а також поховані розсипи золота в алювіальних відкладах середнього еоцену осадового чохла (Гаєва та ін., 2006; Сукач та ін., 1999, 2006).

Сукупний рудоносний потенціал кристалічних та осадових петротипів, їхнє просторово-парагенетичне суміщення, гірничо-геологічні умови локалізації рудовмісних різновікових і різногенетичних товщ, високий ступінь вилучення золота з руд дає змогу стверджувати, що найближчим часом полігенно-поліхронну рудоносну систему Сурської структури (переважно в межах родовищ Сергіївське та Балка Золота) буде залучено до розроблення (Ковальчук, Сукач, 2018). У зв'язку з цим дослідження типоморфних особливостей самородного золота в одній із формаційних одиниць рудоносної системи структури є актуальним. 


\section{АНАЛІЗ ОСТАННIX \\ ДОСЛІДЖЕНЬ І ПУБЛІКАЦІЙ}

Вчення про геологію й корисні копалини кори вивітрювання отримало розвиток завдяки працям Ю.С. Білібіна, І.І. Гінзбурга, В.П. Казарінова, В.П. Петрова, Б.Б. Полинова, І.С. Рожкова, Д.Г. Сапожнікова, С.С. Смірнова, М.М. Страхова та інших дослідників. Історія дослідження кори вивітрювання Українського щита почалася ще в XIX сторіччі та пов'язана з іменами багатьох виробничників, за керівництва яких були здійснені геолого-картувальні та геолого-пошукові роботи в межах окремих територій. Значний внесок у дослідження кір вивітрювання здійснили також науковці, з яких слід виокремити виробничі звіти та наукові праці Ю.О. Авєріна, Ю.Б. Басса, О.Б. Боброва, Л.В. Бочая, А.П. Василенка, С.П. Василенко, М.Ф. Веклича, А.С. Войновського, В.Ф. Володіна, Л.С. Галецького, Ю.Г. Герасимова, А.А. Гончара, О.Д. Додатка, М.М. Дупляка, М.Д. Ельянова, В.Д. Євтєхова, Е.Я. Жовинського, В.М. Жужоми, Р.І. Заболотньої, П.К. Заморія, О.І Зарицького, К.М. Заруцького, П.А. Земятченського, Е.Я. Каплуна, М.С. Ковальчука, В.Ю. Кондрачука, П.К. Корнієнка, М.М. Костенко, Г.О. Кузьманенко, Ю.В. Крошко, Є.О. Куліша, М.І. Лебедя, Г.Д. Лепігова, А.У. Литвиненко, В.Т. Льохового, О.Ф. Маківчука, Е.В. Мельничука, В.С. Металіді, С.В. Нечаєва, В.В. Омельченка, Т.В. Охоліної, Є.С. Перкова, П.Г. Пігулевського, В.Т. Погрібного, С.Є. Поповченка, О.О. Ремезової, Ю.А. Руська, В.А. Рябенка, М.А. Самаріна, Г.С. Соловйова, О.П. Старожука, В.В. Сукача, К.Г. Сущук, Л.Г. Ткачука, О.Ю. Шестакова, І.І. Шоцького, В.І. Шунька та ін.

Тривале дослідження кори вивітрювання знайшло свій відбиток в численних виробничих звітах, наукових публікаціях та монографіях і спонукало вчених і виробничників розглядати кору вивітрювання кристалічних порід як важливий об'єкт вивчення загальної рудоносності щита, а також визначило високий ступінь перспектив рудоносної кори вивітрювання на відкриття нових об'єктів руд чорних, кольорових, рідкісних та благородних металів. 3 останніх провідне місце в економіці усіх країн посіло золото. Під час дослідження золотоносності формаційних одиниць значна увага приділяється дослідженню типоморфних особливостей самородного золота, які слугують інформаційною базою щодо фізико-хімічних параметрів та глибинності рудоутворення.

Золотоносності осадових формаційних одиниць України та мінералогії самородного золота, що міститься в них, присвячені численні наукові публікації, зокрема: Ю.Л. Авєріна, В.М. Артеменка, І.М. Афанасьєвої, Л.В. Бочая, Ю.М. Брагіна, Ю.Ф. Вєліканова, В.В.Грицика, К.М. Заруцького, В.Т. Кардаша, В.М. Квасниці, М.С. Ковальчука, Г.Л. Кравченка, Ю.В. Крошко, Ю.О. Кузнєцова, Є.О. Куліша, Є.К. Лазаренка, І.К. Латиша, М.І. Лебедя, О.І Матковського, М.О. Маслакова, Є.В. Мельничука, С.В. Нечаєва, Б.С. Панова, І.С. Паранько, Ю.О. Полканова, В.П. Рєзніка, М.П. Семененка, К.Г. Сущук, Л.А. Фігури, О.Ю. Шестакова, Є.Ф. Шнюкова, В. О. Шумлянського, С.В. Яблокової, М.Я. Ященка та ін.

Пріоритет у дослідженні золотоносності кори вивітрювання в межах України належить Л. Хрипкову та О. Зайцеву. Надалі золотоносність кори вивітрювання
України в різні роки вивчали І. Абрамов, І. Гаєв, Н. Гаєва, К. Заруцький, М. Ковальчук, П. Корнієнко, Ю. Крошко, $€$. Куліш, Г. Лєпігов, Е. Мельничук, Г. Наумов, С. Нєчаєв, В. Погрібний, В. Сукач, Л. Фігура, О. Шестаков, О. Вишневський та ін. 3 огляду на значний золотоносний потенціал кори вивітрювання України Ю. Авєрін, О. Зарицький, М. Лебідь, О. Маківчук віднесли формацію кори вивітрювання Українського щита до однієї з чотирьох провідних золоторудних формацій і розглядали ії як золото-аргілізитову.

В останні роки пріоритет щодо дослідження типоморфізму самородного золота з кристалічних порід фундаменту, кори вивітрювання та алювіальних відкладів Сурської зеленокам'яної структури належить авторам цієї публікації. Зібраний новий фактичний матеріал спонукає до доповнення раніше отриманих результатів та коригування їх на основі нових даних.

\section{МАТЕРІАЛИ І МЕТОДИ ДОСЛІДЖЕНЬ}

Фактичним матеріалом досліджень слугували матеріали виробничих звітів, власні дослідження, зерна самородного золота, які було досліджено під бінокуляром та за допомогою методів електронно-мікроскопічних і мікрозондових досліджень (на електронному мікроскопі JSM-6700F, обладнаному енергодисперсійною системою для мікроаналізу JED-2300).

\section{ВИКЛАД ОСНОВНОГО МАТЕРІАЛУ}

Золотовміщувальні породи кристалічного фундаменту в межах родовищ золота Сергіївське, Балка Золота та рудопроявів Тетянин, Розрахунковий, Новий, Північний, Південно-Петрівський, Карнаухівський зазнали гіпергенних змін, унаслідок чого частина рудних тіл продовжується у корі вивітрювання, в якій утворює золото-аргілізитову формацію. у більшості випадків кора вивітрювання має площову форму 3 потужністю до 70 м; незначне поширення має лінійний тип кори, який переважно розміщений вздовж розломів і зон розсланцювання, де потужність кори досягає понад 150 м (Гаєва та ін., 2006; Сукач та ін., 2006). У повному профілі кори вивітрювання наявні три зони: I зона - зона дезінтеграції та вилуговування; II зона - зона проміжних продуктів вивітрювання; III зона - зона стійких продуктів вивітрювання. Профіль кори вивітрювання - повний або скорочений (відсутня одна або дві зони). Контури поширення рудних зон у корі вивітрювання приблизно відповідають контурам розвитку корінної золотої мінералізації. Залежно від вихідних порід субстрату та збережених від розмиву їхніх зон кора вивітрювання в межах родовища має кварц-каолінітовий, кварц-серицит-каолінітовий, вохристо-сидерит-каолінітовий, гетит-сидерит-каолінітовий, гідрохлоритовий, гідрохлорит-каолінітовий, гідрогетит-гідрохлоритовий, каолініт-гетит-гідрогетитовий склад (Гаєва та ін., 2006; Сукач та ін., 1999, 2006, Ковальчук, Сукач, 2016).

Загалом зерна золота з кори вивітрювання мають золотисто-жовте, буро-жовте, брудно-жовте забарвлення. Краї зерен - гострі, колючі, округлі, згладжені. Поверхня - 
блискуча, дрібношагренева, кавернозна, з відбитками зерен інших мінералів. Заглиблення на поверхні золотин часто заповнені прозорим і молочно-білим кварцом та залишками зерен магнетиту. Частина золота перебуває в зростках з великими зернами кварцу і магнетитом, який часто має форму правильних кристалів.

Найбільш повно нами досліджено золото з кори вивітрювання родовища Балка Золота (рис. 1).

Золото 3 кварц-каолінітової кори вивітрювання (рис. 2) ксеноморфне: округлої, пластинчастої, дрото-, грудкоподібної і неправильної форми з широким діапазоном форм розміром 0,1-0,2 мм, іноді до 0,3 мм, а також гіпідіоморфне золото у виді псевдокубооктаедричних зерен та їхніх гантелеподібних зростків. Золото середньо- і високопробне (Au - 88,87-94,44\%; $\mathrm{Ag}-3,96-9,33 \%)$. Розмір зерен - 0,1-0,3 мм.

Золото 3 вохристо-сидерит-каолінітової кори вивітрювання - округлої, дротоподібної, неправильної форми розміром 0,1-1,0 мм. В окремих випадках золото наявне у тріщинах зерен магнетиту, всередині стяжінь сидериту й агрегатів гідроокисів заліза. Золото високопробне і дуже високопробне (Au - 92,0-97,2\%; $\mathrm{Ag}-3,7-8,0 \%)$.

Золото з каолініт-гідрохлоритової кори вивітрювання (рис. 3) - неправильної, пластинчастої, грудкоподібної форми з зазубреними гострими краями розміром 0,10,15 мм (переважає) і менше; часто наявні зерна розміром до 0,5 мм. Зустрічаються недосконалі октаедри та октаедри зі згладженими краями. Часто золото наявне на гранях магнетиту і піриту у виді плям або наростає на межі мінералів у виді грудочок, а також у тріщинах кварцу та в зростках із ним. Золото - середньо- і високопробне (Au - 89,4-94,2\%; $\mathrm{Ag}-5,6-10,0 \%)$.

Золото з гідрогетит-гідрохлоритової кори вивітрювання - ізометричної, видовженої в одному напрямку,

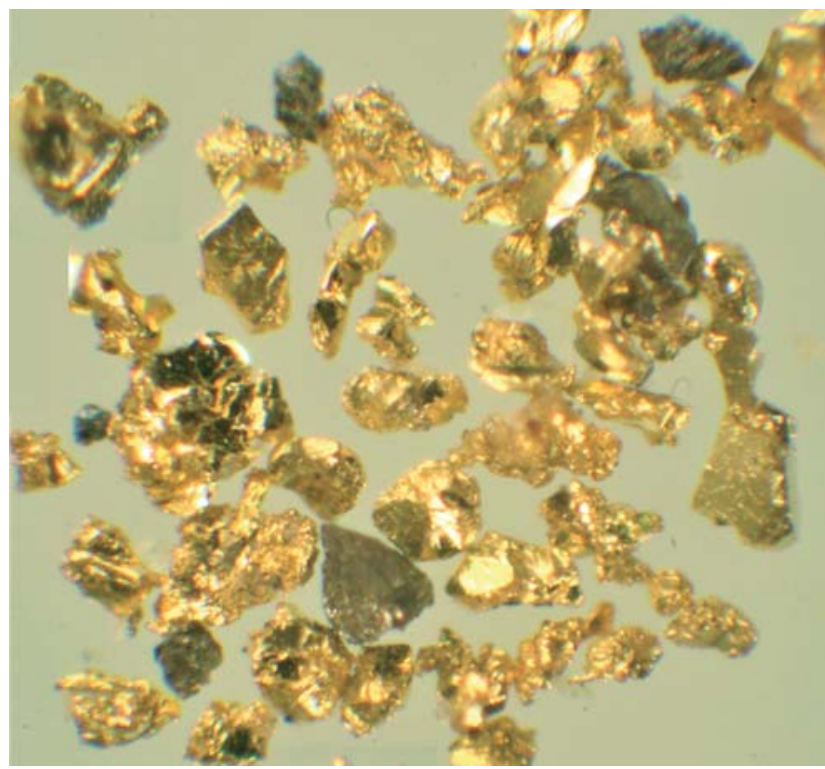
a неправильної форми з гострими краями розміром 0,15 мм і менше, подекуди 0,5-4,5 мм. Наявні зрощення золота з кварцом і зрідка з магнетитом. На поверхні деяких зерен наявна присипка гіпергенного золота. Золото дуже високопробне (Au - 97,5\%; $\mathrm{Ag}-3,1 \%)$.

Золото з каолініт-гетит-гідрогетитової кори вивітрювання - грудкоподібної, ажурної форми часто утворює агрегати з зерен золота неправильної форми. Золото дуже високопробне (Au - 97,7\%; $\mathrm{Ag}-1,7 \%$ ).

Золото з кір вивітрювання рудовмісних кристалічних порід Сергіївського родовища характеризується строкатістю морфологічних форм (рис. 4). У корі вивітрювання Сергіївського родовища майже 90\% становлять зерна золота розміром 0,15 мм і менше. Проба золота - здебільшого 900-958.

Найґрунтовніше досліджено золото з каолінітової кори вивітрювання Північної рудної зони східної частини Сергіївського родовища, яке представлено ідіоморфними зернами (спотвореними кристалами куба і октаедра); гіпідіоморфними зернами з ознаками кристалографічної огранки; ксеноморфними індивідами, які представлені грудкоподібними зернами з численними короткими відростками, ямчасто-пагорбковою поверхнею і включенням прозорого кварцу; об'ємно-видовженими (переважають) зернами неправильної форми зі зрізаними краями, дірочками, блискучою, шагреневою, ямчасто-пагорбковою поверхнею та залишками у поглибленнях звітрених мінералів; ніздрюватими зернами неправильної форми з відростками та включеннями кварцу; золотом із широким діапазоном форм; поодинокими зернами сигароподібної видовженої форми (рис. 5) (Ковальчук, Сукач, Рязанцева, 2019). Зерна золота переважно розміром менше 0,07 мм, подекуди до 0,7 мм; їхній розмір часто збільшується через незакономірні зрощення кількох індивідів. Золото - високопробне

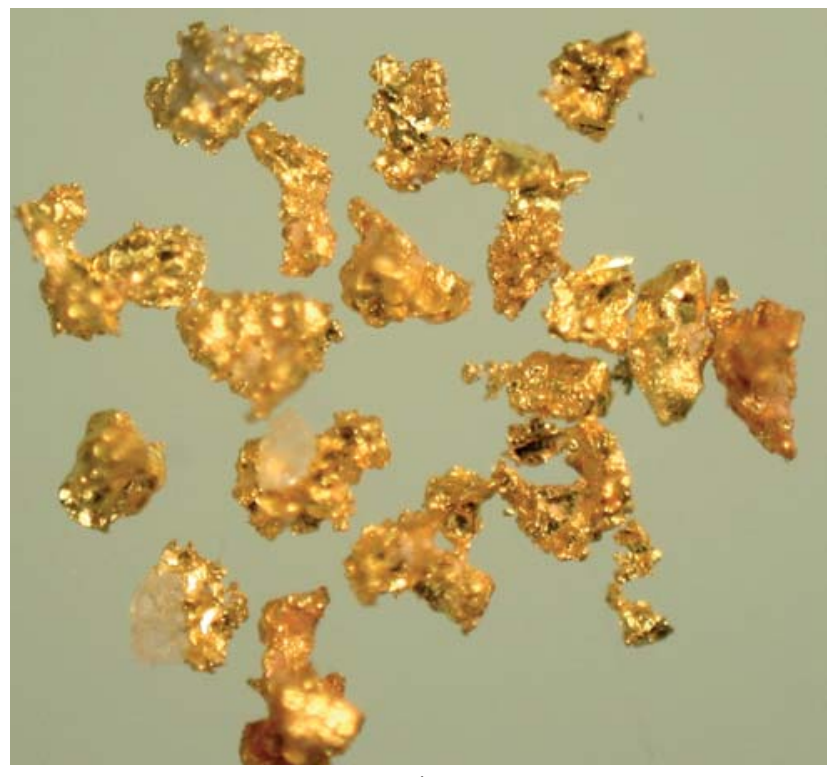

6

Рисунок 1. Розмаїття морфології зерен золота з кори вивітрювання рудоносних кристалічних порід родовища Балка Золота:

а - свердл. 544; б - свердл. 971 


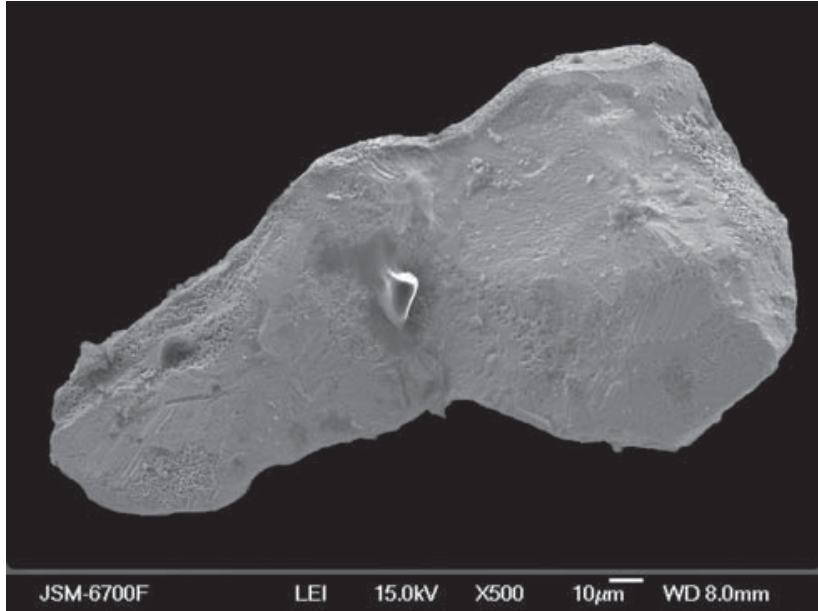

a

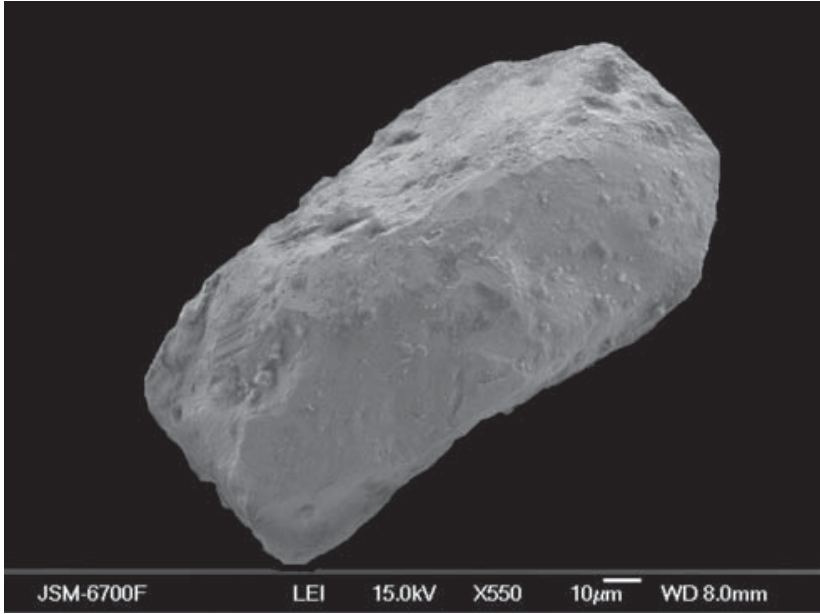

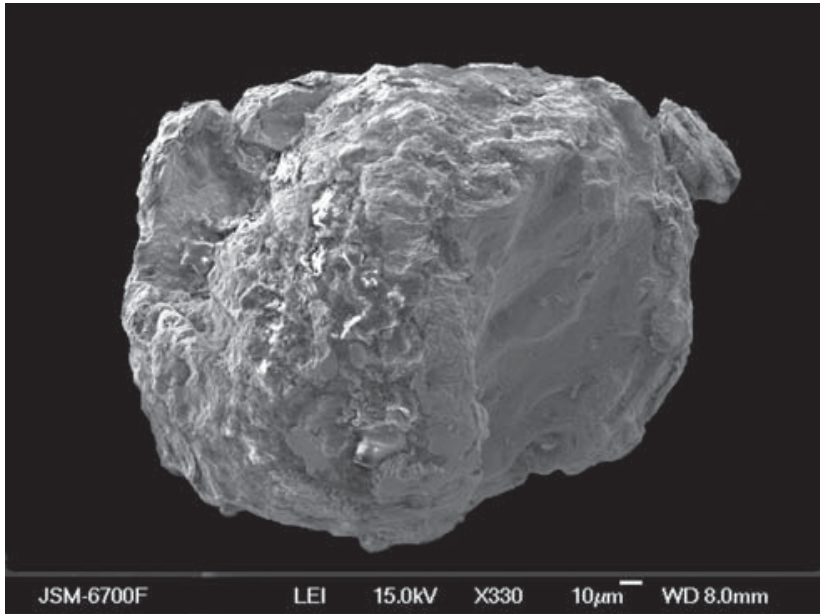

б

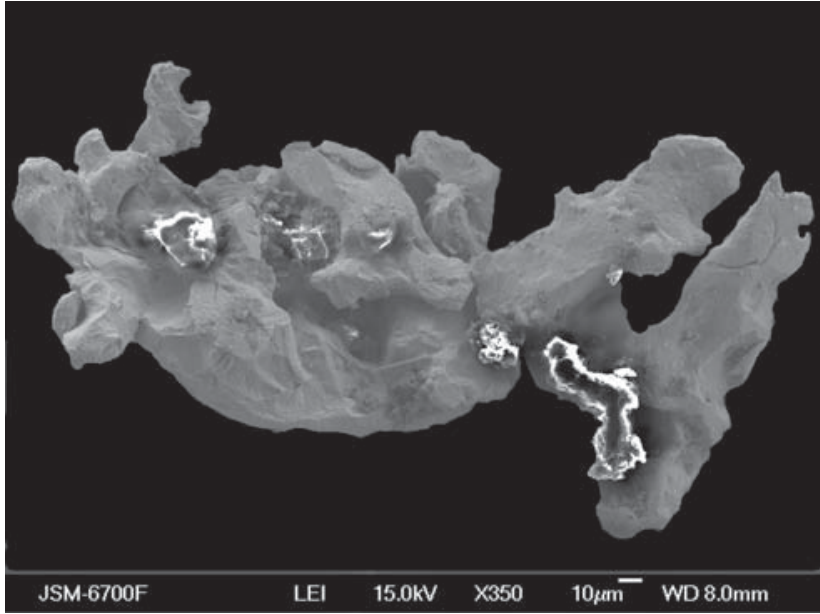

Рисунок 2. Золото з кварц-каолінітової кори вивітрювання (свердл. 3):

а - гіпідіоморфне; б - грудкоподібне; в - дротоподібне; г - з широким діапазоном форм

і дуже високопробне (Au - 90,1-95,4\%; Ag - до 8,73\%; $\mathrm{Cu}$ - до 2,88\%; Zn - до 0,18\%).

У межах рудопрояву Тетянин у каолінітовій корі вивітрювання потужністю 1,0-4,0 м самородне золото ксеноморфне у вигляді грудкоподібної та пластинчастої форми. Розмір зерен - до 0,1 мм.

У межах рудопрояву Розрахунковий у каолінітовій корі вивітрювання потужністю 0,5-4,0 м самородне золото - ксеноморфної форми, наявне у вільному стані і в зрощеннях із кварцом (Ковальчук, Сукач, Гаєва, 2015). Форма зерен - грудкоподібна, неправильна. Розмір золотинок - 0,05-0,15 мм.

У межах рудопрояву Новий у каолінітовій корі вивітрювання потужністю 2,0-4,0 м самородне золото представлено дендритоподібними і друзоподібними зернами розміром до 0,5 мм, а також ксеноморфними зернами луско-, грудкоподібної форми розміром 0,03-0,1 мм (Гаєва та ін., 2006; Ковальчук, Сукач, Гаєва, 2015). Золото високопробне (Au-90,4\%; $A g-9,4 \%)$.

У межах рудопрояву Північний у каолінітовій корі вивітрювання потужністю 3,0 м самородне золото представлене ксеноморфними і геміідіоморфними зернами (Ковальчук., Сукач, Гаєва, 2015). Ксеноморфне золото розміром 0,05-0,4 мм має таблитчасту, округлу й грудкоподібну форму. Геміідіоморфне золото представлене автоепітаксичними наростами золота на золоті.

у межах Південно-Петрівського рудопрояву з каолініт-гетит-гідрогетитової кори вивітрювання потужністю 2,5-4,0 золото досліджено не було.

У межах Карнаухівського рудопрояву з нонтроніт-каолінітової кори вивітрювання золото представлене зернами з ознаками кристалографічної огранки, а також ксеноморфним золотом пластинчастої, короткостовпчастої, округлої, грудкоподібної форм, зрідка пластинчастими зрощеннями (Гаєва та ін., 2006).

Зміну типоморфних особливостей золота (морфології, проби, розміру, забарвлення) у вертикальному розрізі кори вивітрювання було прослідковано на прикладі гідрохлорит-каолінітової кори вивітрювання золотовмісних кристалічних порід фундаменту родовища Балка Золота. Аналіз морфології зерен золота 

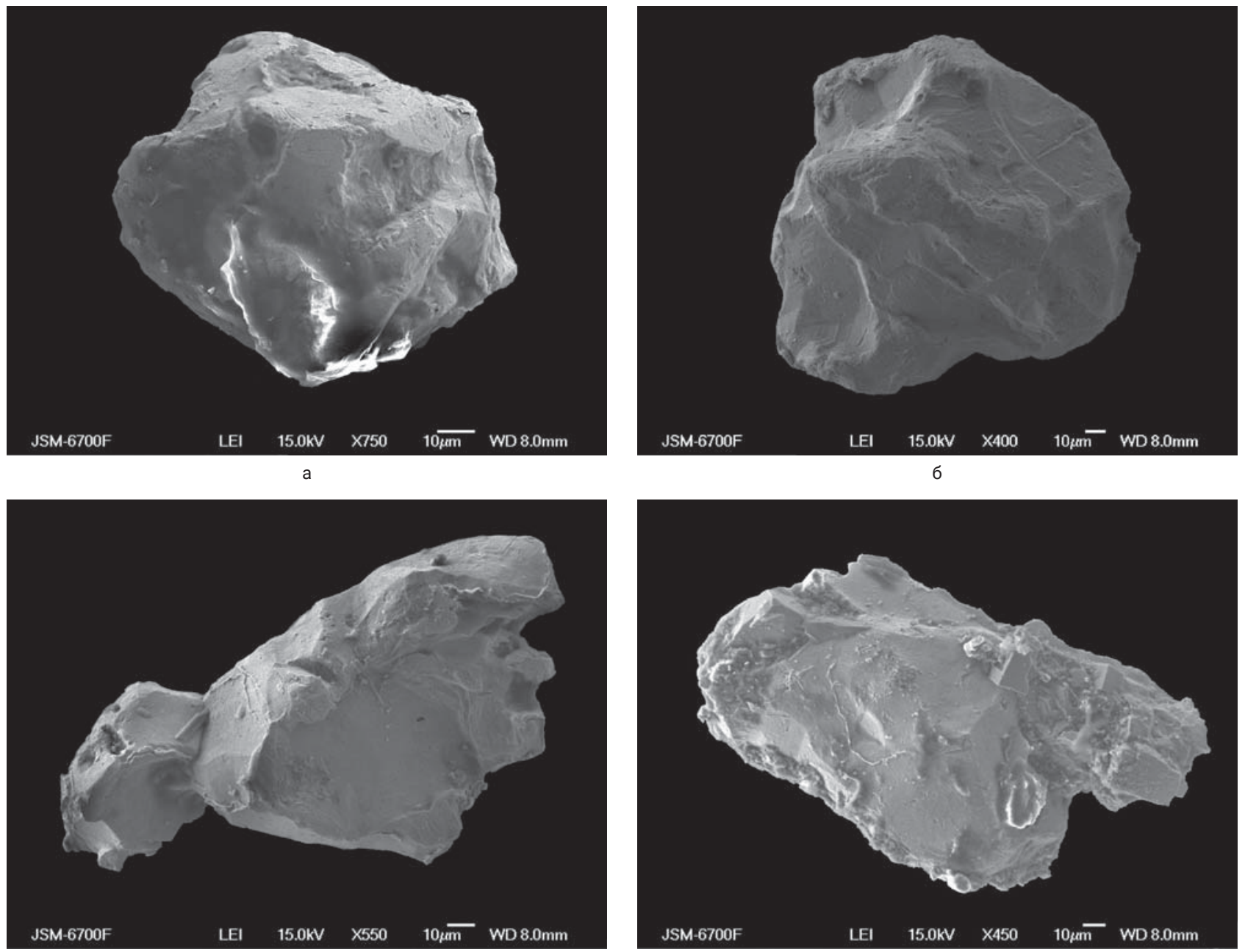

B
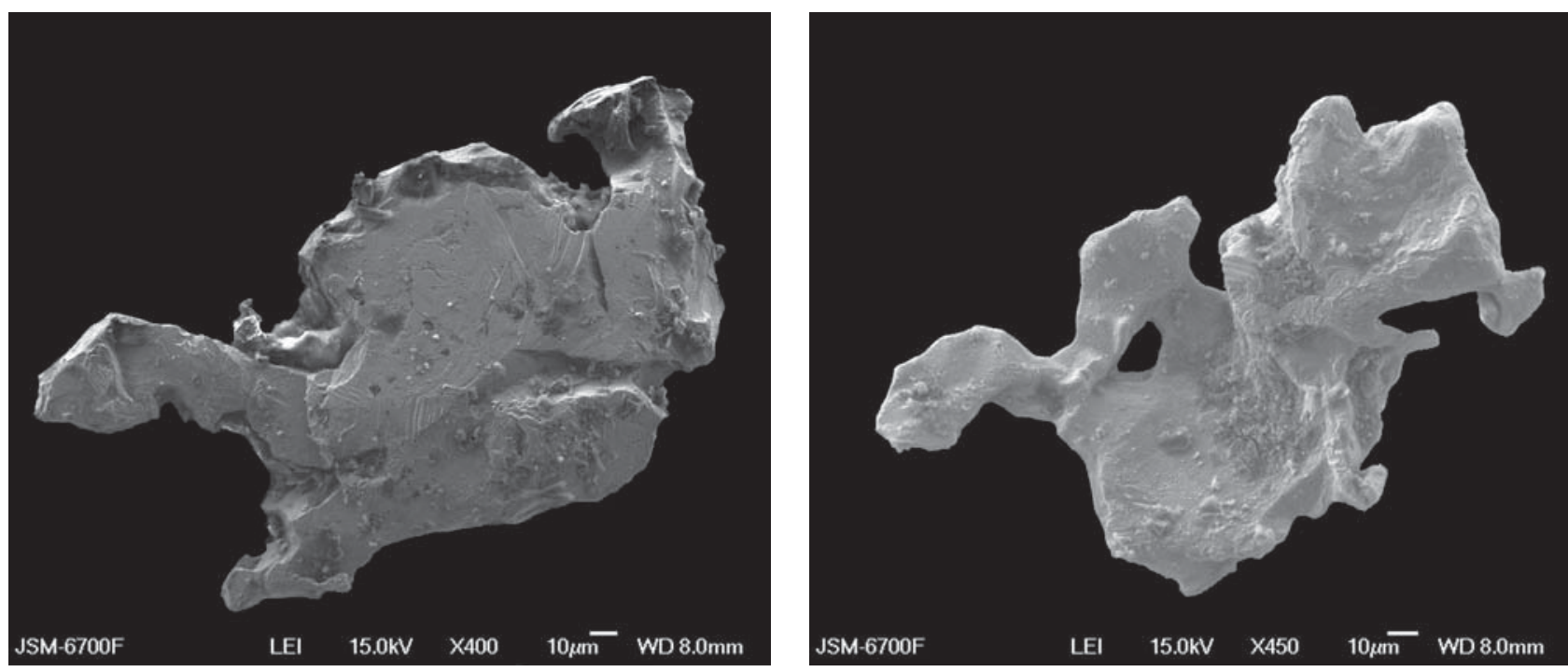

д

e

Рисунок 3. Золото з каолініт-гідрохлоритової кори вивітрювання:

а, б - гіпідіоморфні зерна (свердл. 544); в, г, - грудкоподібні зерна (свердл. 544 і 545);

д, е - золото з широким діапазоном форм (свердл. 544 i 545) 


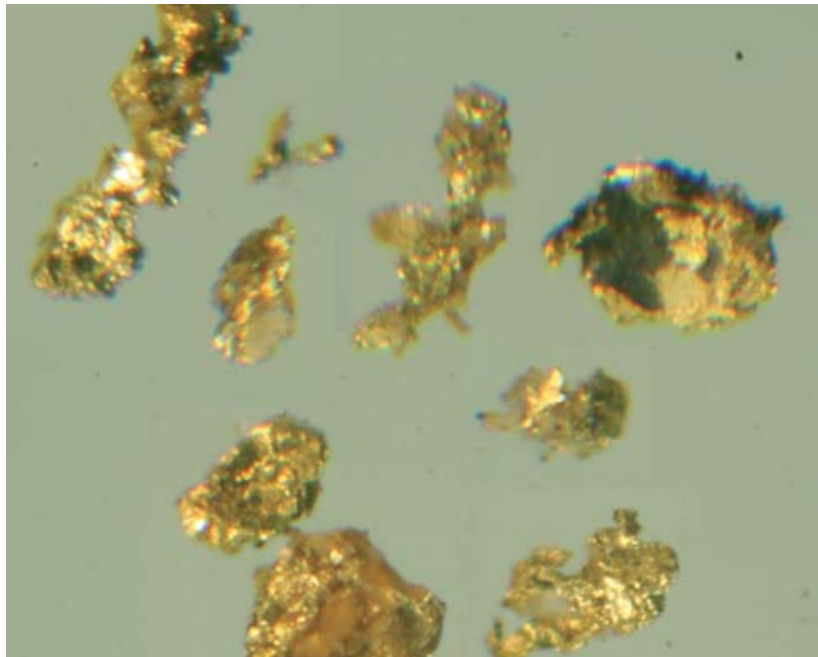

a

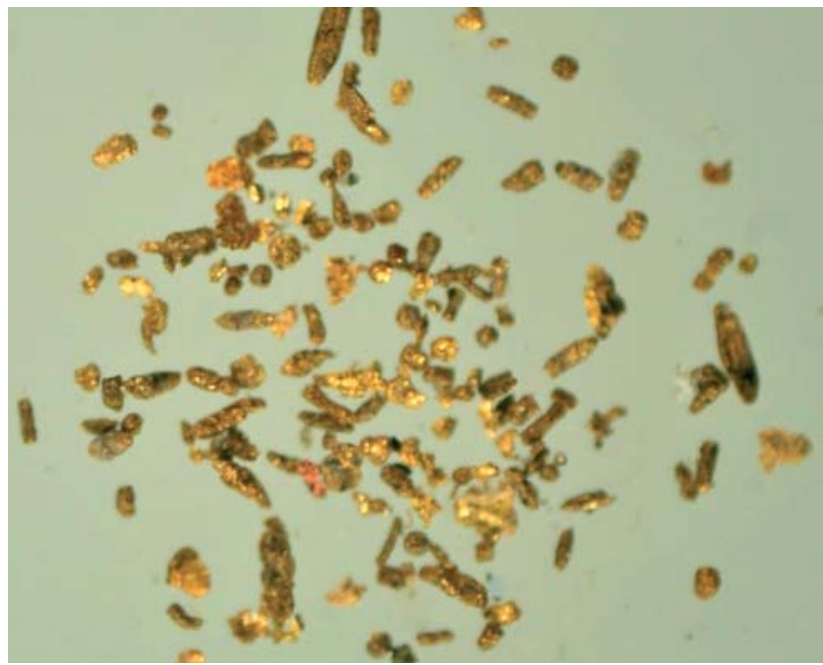

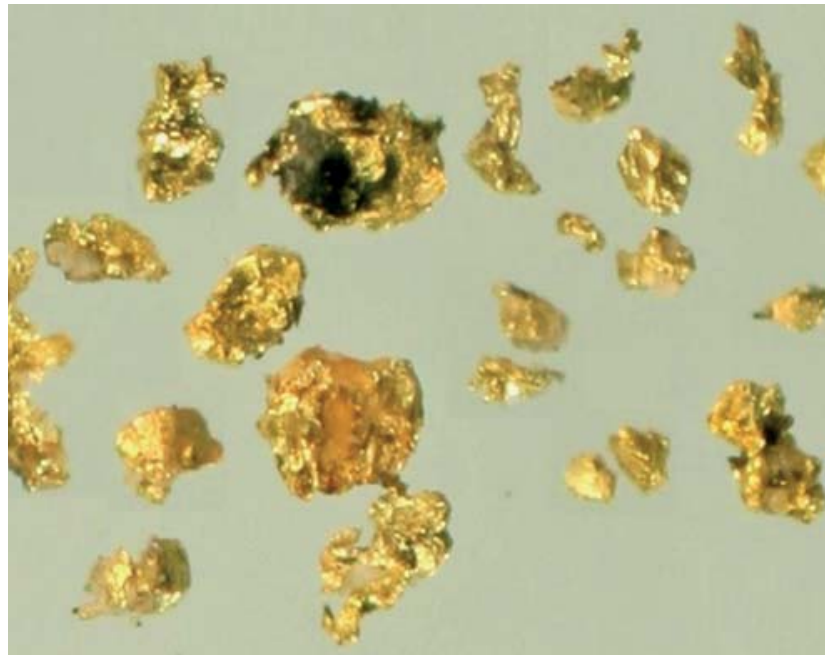

б

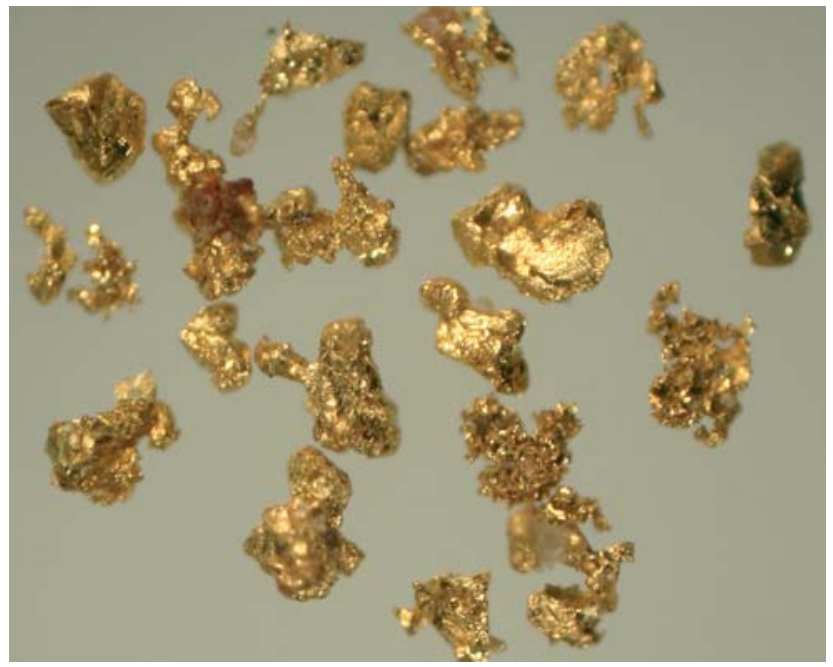

$\Gamma$

Рисунок 4. Розмаїття морфології зерен золота з кори вивітрювання рудовмісних кристалічних порід родовища Сергіївське: а - свердл. 1733; б - свердл. 1911; в - свердл. 1966; г - свердл. 3210

дав змогу зробити висновок, що у верхніх горизонтах кори вивітрювання морфологія зерен більш проста в порівнянні з більш глибокими горизонтами, що, ймовірно, пов'язано зі спрощенням його морфології у верхній зоні елювіальної товщі. Залежно від глибини, у напрямку до незмінених гіпергенезом рудних тіл морфологія зерен золота стає більш строкатою, зокрема, поряд із ксеноморфними зернами з'являються ідіоморфні, гіпідіомофні, геміідіоморфні форми. Також залежно від глибини змінюється проба золота в напрямку від високопробного (в верхніх горизонтах кори вивітрювання) до середньопробного (в нижніх горизонтах кори вивітрювання). Вниз за розрізом забарвлення золота змінюється від золотисто-жовтого до брудно-жовтого, жовто-бурого. Залежно від глибини зменшується також розмір зерен золота.

За результатами фазового аналізу золота, руди з кори вивітрювання належать до легко збагачувальних, кількість вільного золота в них становить 75,17\% (Гаєва та ін., 2006; Сукач та ін., 2006). Золото, яке може бути вилучене традиційними технологічними засобами, становить до 97\% (Сукач та ін., 2006).

\section{ВИСНОВКИ}

Золотоносність кори вивітрювання визначається золотоносністю вихідних порід субстрату. Збільшені концентрації золота приурочені до ділянок підвищення поверхні підошви і покрівлі елювіальної товщі. Мінеральні типи зон кори вивітрювання обумовлені речовинним складом порід субстрату. Повний профіль кори вивітрювання складено трьома зонами, однак у більшості випадків унаслідок розмивання кори вивітрювання профіль елювіальної товщі є скороченим.

Мінералогічні дослідження самородного золота з різних мінеральних типів кір вивітрювання різних зон дали змогу встановити ідіоморфне, гіпідіоморфне, 

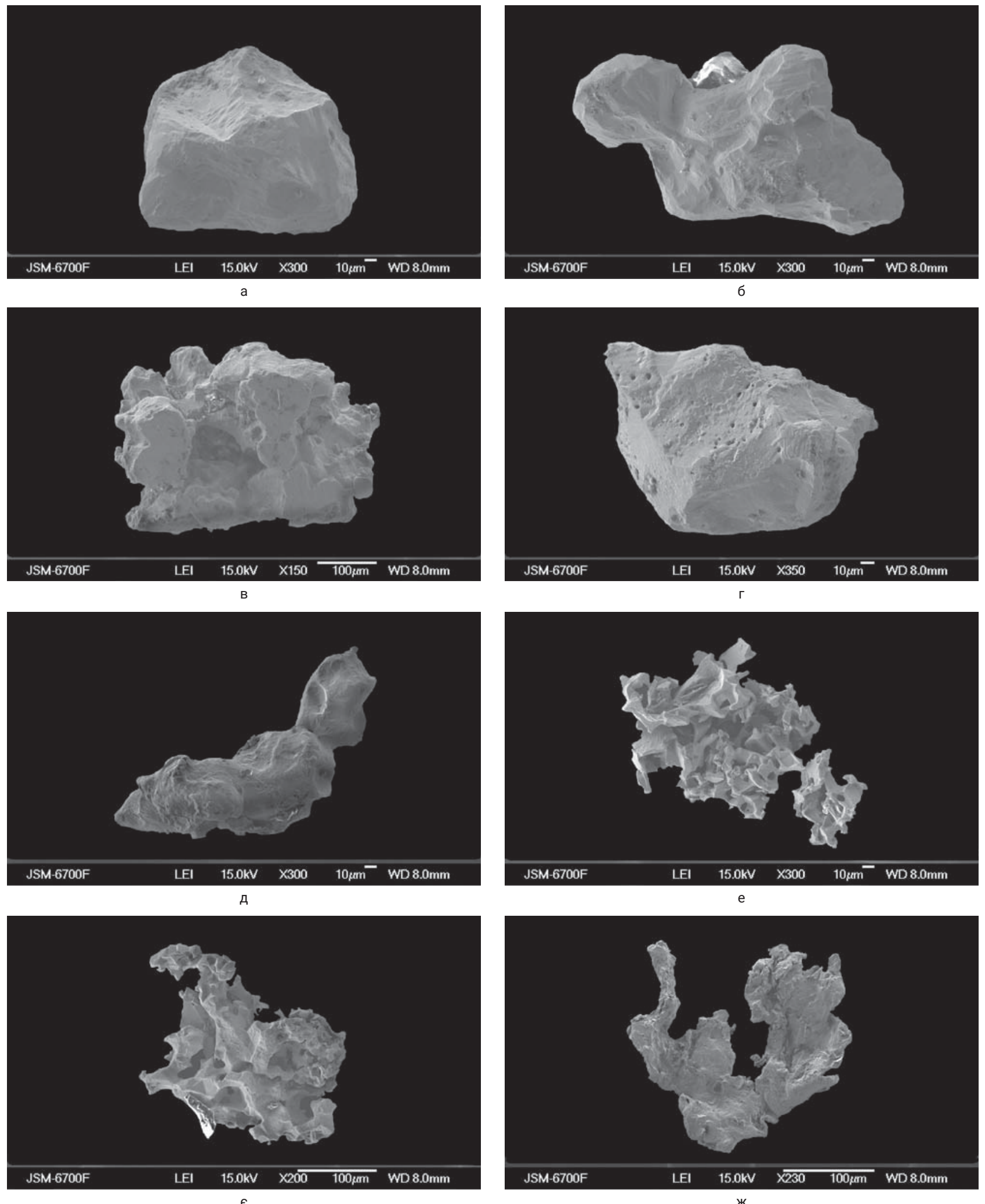

$€$

Рисунок 5. Розмаїття морфології зерен золота з каолінітової кори вивітрювання північної рудної зони східної частини Сергіївського родовища (свердл. 3210):

а - спотворений кристал; б - зростки спотворених кристалів; в - грудкоподібний зросток кількох зерен; г - грудкоподібне зерно;

д - об'ємно видовжене зерно; е, є - ніздрюваті зерна з відростками; ж - ксеноморфне зерно з широким діапазоном форм 
ксеноморфне і геміідіоморфне золото. Завдяки порівняльному аналізу типоморфних особливостей золота з кори вивітрювання та рудних зон незмінених гіпергенезом порід (були досліджені раніше) автори дійшли висновку, що золото в корі вивітрювання переважно залишкове, зрідка з невеликою кількістю новоутвореного, у вигляді дрібних автоепітаксичних наростів золота на золоті.

Гіпергенне перетворення самородного золота в корі вивітрювання виражене у зміні забарвлення, проби та морфології. Збільшення розміру зерен уверх за розрізом кори вивітрювання $€$ віддзеркаленням рудної зональності та частково наслідком укрупнення зерен золота в елювіальній товщі. Зміни типоморфних особливостей самородного золота зростають зі збільшенням гіпергенного перетворення рудоносних порід. Найбільш гіпергенно змінене золото наявне в зоні стійких продуктів вивітрювання.
Золотоносна кора вивітрювання Сурської зеленокам'яної структури містить у значній кількості вільне золото і $€$ достатньо легкозабагачувальною. У зв'язку з цим вона разом із золотоносними породами кристалічного фундаменту й золотоносними континентальними флювіальними утвореннями середнього еоцену, що сформувалися унаслідок розмивання й перевідкладення матеріалу елювію, становлять просторово-парагенетичний ряд різночасових і різногенетичних золотовмісних формаційних одиниць Сурської зеленокам'яної структури, які об'єднані причинно-наслідковими зв'язками й мають загалом значний ресурсний потенціал.

Проведені дослідження типоморфних особливостей самородного золота з кори вивітрювання Сурської зеленокам'яної структури є підґрунтям для створення Атласу самородного золота.

\section{СписОК \\ ВИКОРИСТАНИХ ДЖЕРЕЛ}

Гаєва Н.П. та ін. Особливості речовинного складу самородного золота та золотовміщуючих руд зеленокам'яних комплексів Середнього Придніпров'я: звіт про НДР. Новомосковськ, 2006.

Ковальчук М.С., Сукач В.В. Просторово-парагенетична, полігенно-поліхронна золоторудна система Солонянського рудного поля. Тектоніка і стратиграфія. 2018. № 45. С. 123-132.

Ковальчук М.С., Сукач В.В. Типоморфні особливості самородного золота з кори вивітрювання рудоносних порід Сурської зеленокам'яної структури. Записки Українського мінералогічного товариства. 2016. Т. 13. С. 43-45.

Ковальчук М.С., Сукач В.В., Гаева Н.М. Типоморфные особенности самородного золота из кор выветривания рудоносных пород Сурской зеленокаменной структуры (Среднее Приднепровье, Украина). Минералогия во всем пространстве сего слова: доклады XII Съезда РМО (СПб., 13-16 окт. 2015 г.). СПб., 2015. С. 110-112.

Ковальчук М.С., Сукач В.В., Рязанцева Л.О. Типоморфні особливості самородного золота з кори вивітрювання східного флангу комплексного Au-Мо Сергіївського родовища. Середнє Придніпров'я. Здобутки і перспективи розвитку геологічної науки в Україні: збірник тез наукової конференції, присвяченої 50-річчю Інституту геохімії, мінералогії та рудоутворення імені М.П. Семененка (Київ, 14-16 трав. 2019 р.): у 2 т. Київ, 2019. Т. 2. С. 183-184.

Сукач В.В. и др. Геологическое строение и полезные ископаемые среднего течения р. Мокрая Сура: отчет Сурского геологопоискового отряда о результатах геологического доизучения масштаба 1:50000 южной части Сурской структуры совместно с поисковыми работами на золото в 1989-1999 гг. (листы М-36-142-Б-в,г; -Г-а,б). Новомосковск, 1999.

Сукач В.В., Ковальчук М.С., Гаєва Н.М. Типоморфні особливості золота з рудних зон та кори звітрювання родовища Балка Золота. Мінералогічний збірник. 2014. № 64. Вип. 2. С. 88-94.

Сукач В.В. та ін. Геолого-формаційні типи золотого зруденіння та мінералого-геохімічна характеристика самородного золота зеленокам'яних комплексів Середнього Придніпров'я: звіт про НДР. Дніпропетровськ, 2006.

\section{REFERENCES}

Haieva N.P. ta in. Osoblyvosti rechovynnoho skladu samorodnoho zolota ta zolotovmishchuiuchykh rud zelenokamianykh kompleksiv Serednoho Prydniprovia [Features of the material composition of native gold and gold-bearing ores of greenstone complexes of the Middle Dnieper]: zvit pro NDR [research report]. Novomoskovsk, 2006 (in Ukrainian).

Kovalchuk M.S., Sukach V.V. Prostorovo-parahenetychna, polihenno-polikhronna zolotorudna systema Solonianskoho rudnoho polia [Spatial-paragenetic, polygenic-polychronic gold ore system of Solonyansky ore field]. Tektonika i stratyhrafiia. 2018. No 45. P. 123-132 (in Ukranian).

Kovalchuk M.S., Sukach V.V. Typomorfni osoblyvosti samorodnoho zolota z kory vyvitriuvannia rudonosnykh porid Surskoi zelenokamianoi struktury [Typomorphic features of native gold from the weathering crust of ore-bearing rocks of the Sura greenstone structure]. Zapysky Ukrainskoho mineralohichnoho tovarystva. 2016. Vol. 13. P. 43-45 (in Ukranian). 
Koval'chuk M.S., Sukach V.V., Gaeva N.M. Tipomorfnye osobennosti samorodnogo zolota iz kor vyvetrivanija rudonosnyh porod Surskoj zelenokamennoj struktury (Srednee Pridneprov'e, Ukraina) [Typomorphic features of native gold from the weathering crusts of orebearing rocks of the Sursk greenstone structure (Middle Dnieper, Ukraine)]. Mineralogija vo vsem prostranstve sego slova [Mineralogy in the entire space of this word]: doklady XII S"ezda RMO [reports of the XII Congress of the RMO] (SPb., 13-16 okt. 2015 g.). SPb., 2015. P. 110-112 (in Russian).

Kovalchuk M.S., Sukach V.V., Riazantseva L.O. Typomorfni osoblyvosti samorodnoho zolota z kory vyvitriuvannia skhidnoho flanhu kompleksnoho Au-Mo Serhiivskoho rodovyshcha. Serednie Prydniprovia [Typomorphic features of native gold from the weathering crust of the eastern flank of the Sergievske complex of the Au-Mo deposit. Middle Dnieper]. Zdobutky i perspektyvy rozvytku heolohichnoi nauky v Ukraini [Achievements and prospects for the development of geological science in Ukraine]: zbirnyk tez naukovoi konferentsii, prysviachenoi 50-richchiu Instytutu heokhimii, mineralohii ta rudoutvorennia imeni M.P. Semenenka [proceedings of the scientific conference dedicated to the 50th anniversary of the M.P. Semenenko] (Kyiv, 14-16 trav. 2019 r.): u 2 t. Kyiv, 2019. Vol. 2. P. 183-184 (in Ukranian).

Sukach V.V. i dr. Geologicheskoe stroenie i poleznye iskopaemye srednego techenija r. Mokraja Sura [Geological structure and minerals of the middle course of the Mokraya Sura river]: otchet Surskogo geologo-poiskovogo otrjada o rezul'tatah geologicheskogo doizuchenija masshtaba 1:50000 juzhnoj chasti Surskoj struktury sovmestno s poiskovymi rabotami na zoloto v 1989-1999 gg. (listy M-36-142-B-v, g; -G-a, b) [report of the Sursk geological prospecting detachment on the results of a geological additional survey of 1: 50000 scale of the southern part of the Sura structure in conjunction with prospecting for gold in 1989-1999 (the territory of sheets M-36-142-B-v, g; -G-a, b)]. Novomoskovsk, 1999 (in Russian).

Sukach V.V., Kovalchuk M.S., Haieva N.M. Typomorfni osoblyvosti zolota z rudnykh zon ta kory zvitriuvannia rodovyshcha Balka Zolota [Typomorphic features of gold from the ore zones and the crust of the deposition of the deposit of the Balka Zolota]. Mineralohichnyi zbirnyk. 2014. No 64. Iss. 2. P. 88-94 (in Ukranian).

Sukach V.V. ta in. Heoloho-formatsiini typy zolotoho zrudeninnia ta mineraloho-heokhimichna kharakterystyka samorodnoho zolota zelenokamianykh kompleksiv Serednoho Prydniprovia [Geological formations of gold mineralization and mineralogical-geochemical characteristics of native gold of green-stone complexes of the Middle Dnieper]: zvit pro NDR

[research report]. Dnipropetrovsk, 2006 (in Ukranian).

\section{TYPOMORPHIC FEATURES OF GOLD FROM OF THE SURSK GREENSTONE STRUCTURE WEATHERING CRUST}

Myron

KOVALCHUK

Doctor of Geological Sciences, Professor, head of the department, Institute of Geological Sciences of the National Academy of Sciences of Ukraine, member of the UAG

Vitalii

\section{SUKACH}

\section{Doctor}

of Geological Sciences, head of the department, M.P. Semenenko Institute of Geochemistry, Mineralogy and Ore Formation of the National Academy of Sciences of Ukraine, member of the UAG
Based on the generalization of the actual material of production reports, publications in scientific journals and own research, information on the typomorphic features of native gold from the weathering crust of different mineral composition of gold-bearing rocks within the deposits and ore occurrences of the Sura greenstone structure are given. The change of typomorphic features of gold in the vertical section of the weathering crust is investigated.

Keywords: Middle Dnieper granite-greenstone region; Sura greenstone structure; weathering crust; gold; typomorphic features. 